\title{
Peran Ibu dalam Pengembangan Kecerdasan Matematis-Logis Anak Usia Dini
}

\author{
Warnidah \\ Guru SMAN 16 Bone
}

\begin{abstract}
Logical-mathematical intelligence is an intelligence that needs to be developed in children. This becomes necessary because logical mathematical intelligence has a framework that combines the mathematical and logical sides that become a model for developing children's intelligence which is seen as appropriate for the child's development. In its implementation, mothers have a strategic role given their intense interaction with early childhood.
\end{abstract}

Keywords: Mother, Mathematical Intelligence, Early Children

\section{Pendahuluan}

Pendidikan merupakan suatu proses yang diawali sejak awal usia anak yang lazim disebut dengan usia dini. Proses tersebut tentunya bukan suatu proses yang bersifat instan melainkan proses yang panjang dengan keterlibatan berbagai komponen pendidikan baik dalam konteks rumah tangga, sekolah ataupun masyarakat yang relasi triadik tersebut biasa disebut sebagai tri pusat pendidikan. Dalam kaitannya dengan pendidikan anak usia dini di rumah tangga, ibu merupakan pihak yang memainkan peran yang sangat vital mengingat ibu memiliki waktu yang lebih banyak untuk berinteraksi dengan anak usia dini tersebut.

Dalam lokus pendidikan anak usia dini dalam keluarga, ibu dipandang sebagai salah satu faktor penentu dalam keberhasilan pendidikan anak usia dini mengingat ibu, secara umum, memiliki alokasi waktu yang lebih banyak terhadap anak usia dini dibandingkan dengan ayah. Menyikapi hal tersebut, Ya'qub Chamidi menyatakan bahwa sosok ibu merupakan sosok yang selalu siap siaga dalam memberikan kasih saying dan perhatian terhadap pertumbuhan anakanaknya. Oleh karena itu, sosok ibu menjadi sosok yang memiliki peran yang sangat strategis dalam rumah tangga. ${ }^{86}$ Apa yang digambarkan oleh Ya'qub Chamidi tersebut sebagai peran sentral ibu sebagai orang tua dalam pembinaan anak juga memiliki kerangka teologis-normatif yang dalam hal ini adalah QS. at-Tahrim (66):6 yaitu:

\footnotetext{
${ }^{86}$ Ya'qub Chamidi, Menjadi Wanita Sholehah dan Mempesona, (Jakarta: Mitra Press Studio, 2011), h. 190
} 


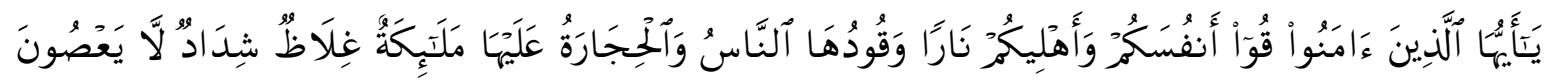

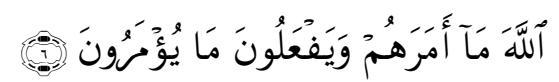

Terjemahnya:

Hai orang-orang yang beriman, peliharalah dirimu dan keluargamu dari api neraka yang bahan bakarnya adalah manusia dan batu; penjaganya malaikat-malaikat yang kasar, keras, dan tidak mendurhakai Allah terhadap apa yang diperintahkan-Nya kepada mereka dan selalu mengerjakan apa yang diperintahkan.

Senada dengan ayat di atas, Muhammad Ali Hasyimi mengemukakan sebuah syair yang dipopulerkan oleh Hafidz Ibrahim dan berkaitan erat dengan posisi ibu dalam rumah tangga sebagai berikut:

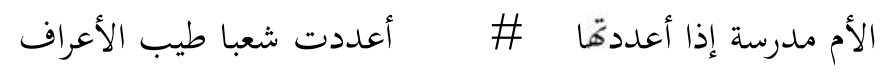

Artinya:

Ibu adalah madrasah, apabila engkau menyiapkannya maka engkau menyiapkan bangsa yang baik pokok pangkalnya.

Mengacu pada ilustrasi di atas, tergambar bagaimana peran sentral seorang ibu dalam pembinaan anak-anak yang pada gilirannya nanti akan menjadi generasi pembangunan pada masa-masa mendatang.

\section{Posisi Ibu dalam Pendidikan Anak Usia Dini}

Masing-masing individu telah diciptakan dengan potensi masing-masing untuk dapat menetralisir berbagai kekurangan-kekurangan yang ada dalam dirinya. Posisi ibu dalam pendidikan anak usia dini dengan segala kelebihan dan kekurangan yang dimilikinya dapat dipahami dari teori psikoanalisa yang dikembangkan oleh Sigmund Freud yang menggambarkan bahwa manusia terdiri atas tiga struktut kepribadian yang dalam hal ini adalah id yang merupakan sifat-sifat biologis yang dibawa oleh manusia sejak lahir dan id ini bekerja pada wilayah yang irasional dalam hal upaya pemenuhan berbagai kepuasan biologis yang pada gilirannya $i d$ menjadi pondasi dalam pembentukan dua struktur berikutnya, ego yang merupakan

${ }^{87}$ QS. at-Tahrim (66):6 
struktur yang imanen pada diri setiap manusia yang bekerja pada wilayah rasional dan berupaya menetralisir letupan-letupan keinginan id dengan menyeimbangkan antara subyektivitas keinginan individu dengan obyektivitas tuntutan realitas sosial, serta superego yang merupakan struktur tertinggi dalam diri setiap individu dengan kemampuan untuk mengarahkan ego bagaimana mengontrol id. ${ }^{88}$ Apa yang digambarkan oleh Sigmund Freud tersebut menunjukkan bahwa ibu sebagai manusia dengan sifat feminisnya memiliki struktur id, ego serta superego yang khas dalam menjalankan fungsi domestikny dalam rumah tangga khususnya alam pembinaan anak usia dini.

Dalam menjalankan posisinya pada pendidikan anak usia dini, Made Pidarta menggambarkan beberapa bentuk pendidikan yang dilakukan oleh ibu-ibu sebagai informan dari penelitian yang dilakukannya. Dari penelitian tersebut, terlihat persentase dari bentuk pendidikan yang dilakuka oleh ibu yaitu member nasehat serta memotivasi tiada henti sebanyak 43,9\%, membiasakan anak untuk membantu pekerjaan di rumah sebanyak 36\%, member contoh yang baik pada anak sebanyak 27,2\%, member semangat belajar pada anak sebanyak 17,5\%, melakukan pengawasan belajar terhadap anak sebanyak $16,7 \%$, menunggu waktu belajar anak sebanyak $10,5 \%$, serta berdialog dengan anak sebanyak $10,5 \% .{ }^{89}$

Sebagai pendamping bagi pendidikan formal sekolah, ibu juga berperan dalam hal pengembangan kecerdasan anak usia dini. Tingkatan kompetensi yang ingin dicapai oleh anak usia dini termaktub dalam Peraturan Menteri Pendidikan dan Kebudayaan Republik Indonesia Nomor 137 Tahun 2014 tentang Standar Nasional Pendidikan Anak Usia Dini adalah usia 4-5 tahun dengan standar tingkat pencapaian perkembangan anak terdiri atas 1) mengetahui agama yang dianutnya, 2) meniru gerakan beribadah dengan urutan yang benar, 3) mengucapkan doa sebelum dan/atau sesudah melakukan sesuatu, 4) mengenal prilaku baik/sopan dan buruk, 5) membiasakan diri berprilaku baik, serta 6) mengucapkan salam dan membalas salam. Usia 5-6

\footnotetext{
${ }^{88}$ Abbas Kararah, Berbicara dengan Wanita, (Jakarta: IKAPI, 1996), h. 152

${ }^{89}$ Made Pidarta, Peranan Ibu dalam Pendidikan Anak, Jurnal Ilmu Pendidikan Jilid 4 Nomor 4 Tahun 1997, h. 245
} 


\section{An-Nisa', Volume XI Nomor 1 Januari 2018}

tahun dengan standar, 1) mengenal agama yang dianut, 2) mengerjakan ibadah, 3) berprilaku jujur, penolong, sopan, dan hormat, 4) menjaga kebersihan diri dan lingkungan, 5) mengetahui hari besar agama, serta 6) menghormati toleransi agama lain. ${ }^{90}$ Dalam proses tersebut, ibu dituntut menjadi pendamping bagi sekolah dalam menguatkan kecerdasan anak.

\section{Kecerdasan Matematis-Logis dan Pengembangannya}

Kecerdasan matematis merupakan suatu bagian kecerdasan seperti yang digambarkan oleh Howard Gardner bahwa kecerdasan majemuk (multiple intelligence) yang ada pada manusia paling tidak bisa dibagi menjadi beberapa jenis yang dalam hal ini adalah kecerdasan bahasa (linguistic intelligence), kecerdasan matematis-logis (logical-mathematic intelligence), kecerdasan visual (visual intelligence), kecerdasan musical (musical intelligence), kecerdasan kinestetis (kinesthetic intelligence), kecerdasan interpersonal (interpersonal intelligence), kecerdasan intrapersonal (intrapersonal intelligence), kecerdasan naturalis (naturalistic intelligence) serta kecerdasan ekstensial (extensial intelligence). ${ }^{91}$

Berbagai kecerdasan di atas memiliki kerangka penjabaran masing-masing dengan eksistensi pada setiap individu cenderung berbeda-beda. Menyikapi hal tersebut, Amir Hamzah mengemukakan bahwa setiap anak memiliki kecerdasan yang mungkin saja berbeda satu sama lain. Anak akan lebih mudah memahami pelajaran jika materinya disajikan sesuai dengan inteligensi yang menonjol dalam diri anak. Misalnya, bila anak menonjol dalam inteligensi musikal, ia akan mudah memahami mata pelajaran tertentu, misalnya biologi, jika dijelaskan dengan memasukkan unsur musik ke dalamnya. Jika anak menonjol dalam inteligensi visual, ia akan lebih mudah menangkap pelajaran jika dijelaskan menggunakan bermacam-macam bentuk yang dapat diamati. Konsekuensinya, keberagaman inteligensi yang dimiliki oleh anak di kelas menuntut pendidik perlu memasukkan dan mengolah materi yang akan diajarkan sesuai dengan

\footnotetext{
${ }^{90}$ Republik Indonesia, "Peraturan Menteri Pendidikan dan Kebudayaan Republik Indonesia Nomor 137 Tahun 2014 tentang Standar Nasional Pendidikan Anak Usia Dini, (Jakarta: Menteri Pendidikan dan Kebudayaan Republik Indonesia, 2015), h. 8-9

${ }^{91}$ Paul Suparno, Teori Inteligensi Ganda dan Aplikasinya di Sekolah, (Yogyakarta: Kanisius, 2004), h. 19
} 
inteligensi anak tersebut. Mereka perlu mengajar dengan model bervariasi sehingga setiap anak merasa dibantu secara tepat. Karena itu, akan sangat baik jika sebelum mengajar, setiap guru mencoba mengenali inteligensi apa saja yang dimiliki anak didiknya. ${ }^{92}$

Dalam kaitannya dengan kecerdasan matematis-logis, Tadkiroatun Musfiroh menggambarkan beberapa karakteristik yang bisa digunakan dalam mengidentifikasi anak yang memiliki kecerdasan matematis-logis sebagai berikut:

1. Kesenangan mereka terhadap angka-angka, mampu membaca angka, dan berhitung. Anak yang cerdas dalam logis-matematis cepat dan efektif dalam menjumlah, mengurangi, dan membaca simbol angka

2. Kemahiran mereka berpikir dan menggunakan logika. Anak yang cerdas logis-matematis mampu memecahkan masalah secara logis, cepat memahami permasalahan, mampu menelusuri sebab dan akibat suatu masalah.

3. Kesukaan mereka bertanya dan selalu ingin tahu

4. Kecenderungan mereka untuk memanipulasi lingkungan dan menggunakan strategi cobaralat, serta menduga-duga dan mengujinya.

5. Kecenderungan mereka untuk bermain konstruktif, bermain dengan pola-pola, permainan strategi, menikmati permainan dengan komputer atau kalkulator.

6. Kecenderungan untuk menyusun sesuatu dalam kategori atau hierarki seperti urutan besar ke kecil, panjang ke pendek, dan mengklasifikasi benda-benda yang memiliki sifat sama. 93

Kecerdasan matematis-logis adalah kemampuan seseorang dalam memecahkan masalah. Ia mampu memikirkan dan menyusun solusi (jalan keluar) dengan urutan yang logis (masuk akal). Ia suka angka, urutan, logika dan keteraturan. Ia mengerti pola hubungan, ia mampu melakukan proses berpikir deduktif dan induktif. Proses berpikir deduktif artinya cara berpikir

\footnotetext{
${ }^{92}$ Amir Hamzah, Teori Multiple Intelligence dan Implikasinya terhadap Pengelolaan Pembelajaran, Jurnal Tadris Volume IV Nomor 2 Tahun 2009, h. 255

93 Tadkiroatun Musfiroh, Hakikat Kecerdasan Majemuk, http://repository.ut.ac.id. (12 Desember 05 Mei 2018)
} 


\section{An-Nisa', Volume XI Nomor 1 Januari 2018}

dari hal-hal yang besar kepadahal-hal yang kecil. Proses berpikir induktif artinya cara berpikir dari hal-hal yang kecil kepada hal-hal yang besar. Ini adalah jenis keterampilan yang sangat dikembangkan pada diri insinyur, ilmuwan, ekonom akuntan, detektif, dan para anggota profesi hukum. Orang yang mempunyai inteligensi matematis-logis sangat mudah membuat klasifikasi dan kategorisasi dalam pemikiran serta cara mereka bekerja. Dalam menghadapi banyak persoalan, dia akan mencoba mengelompokkannya sehingga mudah dilihat mana yang pokok dan yang tidak, mana yang berkaitan antara yang satu dengan yang lain, serta mana juga yang merupakan persoalan lepas. Maka, dia tidak mudah bingung. Mereka juga macam sehingga dapat melihat inti persoalan yang dihadapi dengan jelas.

\section{Peran Ibu dalam Pengembangan Kecerdasan Matematis Anak Usia Dini}

Dalam upaya mengembangkan kecerdasan matematis anak usia dini, ibu berperan sebagai akselerator utama mengingat alokasi waktu yang dimiliki oleh seorang ibu pada umumnya lebih banyak dibandingkan dengan seorang ayah.

belajar terbaik anak-anak yang cerdas logis-matematis adalah melalui angka, berpikir, bertanya, mencoba, menduga, menghitung, menimbang, mengurutkan, mengklasifikasi, dan mengonstruksi. Oleh karena itu, sediakan alat-alat bermain konstruktif, puaskan rasa ingin tahu anak, dan beri kesempatan anak untuk bertanya, menduga, dan mengujinya. ${ }^{94}$

Kecerdasan terbentuk ketika pertumbuhan struktur dan fungsi otak mencapai tahap tertinggi. Kondisi ini terjadi selama rentang waktu 12 tahun pertama. Selama rentang waktu 0-3 tahun dan 6-9 tahun merupakan kondisi terbesar jumlah pembentukan jalur koneksi yang kemungkinan hilangnya jalur koneksi dan kemungkinan hilangnya jalur tersebut pada sistem saraf. Koneksi yang menghasilkan persepsi baik atau positif selaras dengan nilai-nilai kecerdasan yang harus dibentuk semaksimal mungkin. Sebaliknya koneksi sel-sel saraf yang menghasilkan persepsi buruk harus dicegah dan diputuskan jika telah terjadi. Pada anak usia 0-3 tahun terjadi proses pertumbuhan sel-sel saraf serta pembentukan koneksi (hubungan antara sel-sel saraf).

${ }^{94}$ Tadkiroatun Musfiroh, Hakikat Kecerdasan Majemuk, http://repository.ut.ac.id. (12 Desember 05 Mei 
Setelah berumur 4-5 tahun, pertumbuhan otak akan mencapai 80\%. Pengaruh pada perkembangan neuron dalam SSP (sistem saraf pusat) akan meningkatkan kemampuan daya pikir yang lebih kompleks. Penyerapan informasi dari luar diri semakin banyak. Selanjutnya ketika anak usia anak mencapai 6 tahun lebih terjadi perluasan ruang gerak serta hubungan sosial yang lebih rumit. Kondisi ruang gerak dan peluasan lingkungan memberi informasi yang semakin banyak dan berubah-ubah. Inilah masa-masa ideal untuk meningkatkan kemampuan fungsional dari struktur otak yang telah terbentuk. ${ }^{95}$

Dalam upaya mengembangkan kecerdasan matematis-logis, ibu dapat memberikan stimulus-stimulus pendidikan berupa analisis logis seperti dengan bercerita bahwa apabila seseorang memiliki 6 buah permen lalu diberikan pada temannya 6 permen maka berapa permen tersisa. Dalam upaya ini, ibu menjadi pihak yang paling sering bersentuhan dengan anak sehingga penguatan kecerdasan matematis-logis anak usia dini menjadi peluang bagi ibu.

\section{Kesimpulan}

Kecerdasan matematis-logis merupakan salah satu kecerdasan yang perlu dikembangkan pada anak. Hal ini menjadi perlu karena kecerdasan matematis-logis memiliki kerangka kerja yang memadukan sisi matematika dan logika yang menjadi suatu model pengembangan kecerdasan anak dipandang sesuai dengan perkembangan anak. Dalam implementasinya, ibu memiliki peran yang strategis mengingat

\section{Daftar Pustaka}

Chamidi, Ya'qub, Menjadi Wanita Sholehah dan Mempesona, Jakarta: Mitra Press Studio, 2011. Kararah, Abbas, Berbicara dengan Wanita, Jakarta: IKAPI, 1996.

Pidarta, Made, Peranan Ibu dalam Pendidikan Anak, Jurnal Ilmu Pendidikan Jilid 4 Nomor 4 Tahun 1997.

Suparno, Paul, Teori Inteligensi Ganda dan Aplikasinya di Sekolah, Yogyakarta: Kanisius, 2004. Hamzah, Amir, Teori Multiple Intelligence dan Implikasinya terhadap Pengelolaan Pembelajaran, Jurnal Tadris Volume IV Nomor 2 Tahun 2009.

\footnotetext{
${ }^{95}$ Sutan Surya, Melejitkan Multiple Intelligence Sejak Dini, (Yogyakarta: Andi, 2007), h. 1
} 


\section{An-Nisa', Volume XI Nomor 1 Januari 2018}

Musfiroh, Tadkiroatun, Hakikat Kecerdasan Majemuk, http://repository.ut.ac.id. (12 Desember 05 Mei 2018)

Surya, Sutan, Melejitkan Multiple Intelligence Sejak Dini, Yogyakarta: Andi, 2007. 